\title{
Effects of live feed containing Panagrellus redivivus and water depth on growth of Betta splendens larvae
}

\author{
Márcia Valéria Silva do Couto ${ }^{1}$ | Natalino da Costa Sousa ${ }^{1}$ | Higo Andrade Abe ${ }^{1}$ | \\ Joel Artur Rodrigues Dias ${ }^{1}$ (B) | Juliana Oliveira Meneses ${ }^{2}$ | Peterson Emmanuel \\ Guimarães Paixão ${ }^{2}$ (D) | Fernanda dos Santos Cunha ${ }^{2}$ (D) | Fabrício Menezes Ramos ${ }^{3}$ | \\ Alexandre Nizio Maria ${ }^{4}$ | Paulo Cesar Falanghe Carneiro ${ }^{4}$ | Rodrigo Yudi Fujimoto ${ }^{4}$
}

\author{
${ }^{1}$ Post-graduation in Animal Science, Federal \\ University of Pará (UFPA), Belém, PA, Brazil \\ ${ }^{2}$ Post-graduation in Health and \\ Environmental, Tiradentes University \\ (UNIT), Aracaju, Sergipe, Brazil \\ ${ }^{3}$ Federal Institute of Education Science and \\ Technology (IFPA), Cametá, Pará, Brazil \\ ${ }^{4}$ Brazilian Agricultural Research Corporation \\ (EMBRAPA), Aracaju, Sergipe, Brazil \\ Correspondence \\ Rodrigo Yudi Fujimoto, EMBRAPA- Brazilian \\ Agricultural Research Corporation Tabuleiros \\ Costeiros. Av Beira Mar 3250 49025-040 - \\ Aracaju, SE, Brazil. \\ Email: ryfujim@hotmail.com \\ Funding information \\ Conselho Nacional de Desenvolvimento \\ Científico e Tecnológico, Grant/Award \\ Number: 305195/2016-6
}

\begin{abstract}
Panagrellus redivivus is a nematode with a high protein content and low-cost production. It is successfully used in the larviculture of shrimp, however, it has not yet been evaluated as feed for Betta splendens larvae. Thus, the objective of this study was to evaluate $P$. redivivus as feed for betta larvae maintained at different depths of water. The experiment was based on a completely randomized $3 \times 2$ factorial design, represented by two feed types and one alternating feeding regime plus two water depths $(2.5$ and $5.0 \mathrm{~cm}$ ). The Artemia feed promoted the highest weight gain, followed by the alternating feeding regime. The single use of the nematode as live feed produced the poorest weight gain. The water depth and the feeding method influenced the specific growth rate (SGR). At a depth of $2.5 \mathrm{~cm}$, the alternating feeding promoted similar SGR compared to fish fed with Artemia only. Furthermore, at the greater water depth an improvement in SGR was observed in fish fed Artemia only, but the similarity to alternating feeding regime remains. Thus, the inclusion of nematode is an appropriate and lower cost feed strategy for the betta larviculture independent of water depths.
\end{abstract}

KEYWORDS

betta, feed, larvae, Panagrellus redivivus

\section{1 | INTRODUCTION}

Betta splendens is an important species in the international ornamental fish trade due its coloured patterns and singular behaviour. Reproduction and larviculture are a challenge for many producers due to the lack of scientific information, mainly on the nutrition of early larvae (Puello-Cruz, Velasco-Blanco, Martínez-Rodríguez, FelixRamos, \& Voltolina, 2010).

Adequate feed and nutrition influence the quality of larvae, maximizing their zootechnical performance and immune response (Kim, 2007; Lazzari, Neto, Lima, Pedron, \& Losekann, 2004). Live feeds (such as Artemia and Daphnia sp.) are commonly used in larviculture, due to the high quality of protein and lipid profile (essential fatty acids), even assisting in the development of the digestive system (Kolkovski, 2001; Soares, Hayashi, Gonçalves, Galdioli, \& Boscolo, 2008). Among the live feeds, the microcrustacean Artemia is commonly used for betta larviculture. The Artemia is rich in protein, vitamin, and minerals. However, its utilization has high economic cost (Das, Mandal, Bhagabati, Akhtar, \& Singh, 2012). Therefore, feed alternatives, such as the microworm (MV) Panagrellus redivivus, should be evaluated which take into consideration market availability, ease of cultivation, fish productivity performance, and reduction in costs.

Panagrellus redivivus is a free-living nematode of small size $(50$ $2,000 \mu \mathrm{m}$ length and $50 \mu \mathrm{m}$ diameter), suitable for fish larvae with reduced mouth size, such as the betta larvae that have a mouth 


\begin{tabular}{lccc}
\hline Feed & \multicolumn{1}{c}{ Artemia } & Alternating feeding regime & Panagrellus redivivus \\
\hline Total ammonia $(\mathrm{mg} / \mathrm{L})$ & $0.71 \pm 0.1 \mathrm{~A}$ & $0.90 \pm 0.20 \mathrm{AB}$ & $1.5 \pm 0.1 \mathrm{~B}$ \\
\hline Dissolved oxygen $(\mathrm{mg} / \mathrm{L})$ & $4.84 \pm 0.60 \mathrm{~A}$ & $4.04 \pm 0.31 \mathrm{~A}$ & $3.95 \pm 0.36 \mathrm{~A}$ \\
\hline Temperature $\left({ }^{\circ} \mathrm{C}\right)$ & $26.59 \pm 0.13 \mathrm{~A}$ & $26.70 \pm 0.18 \mathrm{~A}$ & $26.67 \pm 0.12 \mathrm{~A}$ \\
$\mathrm{pH}$ & $7.65 \pm 0.003 \mathrm{~A}$ & $7.51 \pm 0.002 \mathrm{~B}$ & $7.46 \pm 0.003 \mathrm{~B}$ \\
\hline Electric conductivity $(\mu \mathrm{S})$ & $307.06 \pm 33.74 \mathrm{~A}$ & $258.06 \pm 69.64 \mathrm{~A}$ & $241.25 \pm 82.60 \mathrm{~A}$ \\
\hline
\end{tabular}

TABLE 1 Mean values of water quality parameters in larviculture of Betta splendens treated with different feeds

Different letters in rows present significant difference $5 \%$ by the Tukey test.

opening of $420 \mu \mathrm{m}$ at 8 days after hatching (Budiardi, Nursyams, \& Sudrajat, 2005). This nematode has a high protein level (crude protein $60 \%$ of dry matter, Sautter, Kaiser, Focken, \& Becker, 2007), well-defined large-scale and reduced cost production with up to 500,000 nematodes/g of culture medium (Sautter et al., 2007).

There are no published reports concerning the use of this nematode as feed for betta larvae. However, it was evaluated as feed for angel fish Pterophyllum scalare larvae, but promoted lower performance compared to Artemia franciscana and Moina wierzeiski (LunaFigueroa, Vargas, \& Figueroa, 2010). This finding may be associated with two hypotheses: the composition of its cuticle is indigestible for angel fish larvae (Luna-Figueroa et al., 2010), or sinking of the microworm at time of feeding makes it difficult to capture in deep water (Sautter et al., 2007).

In the case of betta larviculture, water depths $>8 \mathrm{~cm}$ cause mortality and elevated cost of feeding due to increasing fish movement required for capture of the prey and the need for larvae to realize the first air breathing (Kim, 2007). For these reasons, a combination of water depth and nematode availability in betta larviculture presents a hypothesis for elucidating the problem of using $P$. redivivus in larviculture of fish.

Thus, the aim of this study was to evaluate the use of $P$. redivivus and different water depths on the growth performance of B. splendens larvae.

\section{2 | MATERIALS AND METHOD}

The larvae were obtained from natural spawning according to the reproductive methodology described by Faria et al. (2006). After mouth opening and horizontal swimming, the larvae were fed with the Paramecium sp. protozoa four times a day (Budiardi et al., 2005). On the fifth day after hatching, the larvae were distributed to cylindrical tanks with a 5-L capacity in a static system without aeration. The water parameters of $\mathrm{pH}\left(\mathrm{YSI}^{\mathrm{TM}}\right.$ 60), temperature ( $\mathrm{YSI}^{\mathrm{TM}}$ 60), dissolved oxygen $\left(\mathrm{YSI}^{\mathrm{TM}} 30\right.$ ) and electric conductivity $\left(\mathrm{YSI}^{\mathrm{TM}}\right)$ were monitored daily. Total ammonia was measured at the end of experiment (Hanna ${ }^{\mathrm{TM}}$ HI 93715).

The animals were maintained at a density of 34 larvae/litre of water. The experiment was based on a completely randomized $3 \times 2$ factorial design, represented by two feed types and one alternating feeding regime plus two water depths $(2.5$ and $5.0 \mathrm{~cm}$ corresponding to water volume of 295 and $590 \mathrm{ml}$ respectively) over a period of 7 days, with three replicates. The larvae were fed four times per day with: (a) 500 P. redivivus (NM/larvae/feed); (b) 200 Artemia (Artemia nauplii/larvae/feed); (c) alternating feeding regime with 500 (NM/larvae/feed) (Schlechtriem, Ricci, Focken, \& Becker, 2004) and 200 (Nauplii/larvae/feed) (Fabregat et al., 2017) distributed alternately in two meal each. At the end of each day was carried out water exchange ( $20 \%$ of total volume).

The nematodes were acquired from local trade and then cultivated in oatmeal moistened with water and kept in an aerated container at environmental temperature according to De Lara, Castro, Castro, and Castro (2007) and filtered by a mesh (size $500 \mu \mathrm{m}$ ) before offered to larvae. The Artemia was acquired as an Artemia cyst (INVE) and offered to larvae as early hatched Nauplii. After the experimental period (15 days), all larvae were collected with the aid of pipette Pasteur, weighted on analytical balance (Marte) at $0.002 \mathrm{~g}$ precision and counted for determination of survival rate. Animals were collected and the zootechnical parameters of weight gain (WG), specific growth rate (SGR), and lot uniformity were determined according to previous studies (Furuya, de Souza, Furuya, Hayashi, \& Ribeiro, 1998; Ramos, Abe, \& Fujimoto, 2016).

Data obtained for water quality, zootechnical performance, and survival were analysed using the normality tests of Shapiro-Wilk and, for homoscedasticity, using the Bartlett test, and then subjected to two-way analysis of variance (ANOVA) and the Tukey post hoc test ( $5 \%$ probability) for the comparison of mean values.

\section{3 | RESULTS}

The feed type and water depth did not show any significant interaction $(p>0.05)$. The parameters of dissolved oxygen, temperature, and electrical conductivity of water remained constant independent of the feed used. However, the concentration of total ammonia was higher with feed exclusively using nematodes, and an increase in $\mathrm{pH}$ was observed with Artemia feed (Table 1).

The water depth did not influence the parameters of dissolved oxygen, temperature, and total ammonia. However, increased $\mathrm{pH}$ and electrical conductivity of water were observed at a water depth of $2.5 \mathrm{~cm}$ (Table 2).

As with the water quality parameters, there was no interaction observed among the feed types and water depths with regard to the parameters of survival and zootechnical performance, except for SGR (Table 3 and 4). 
TABLE 2 Mean values of water quality parameters in larviculture of Betta splendens at different water depths

\begin{tabular}{lrr} 
Water column & \multicolumn{1}{c}{$2.5 \mathrm{~cm}$} & \multicolumn{1}{c}{$5.0 \mathrm{~cm}$} \\
\hline Total ammonia $(\mathrm{mg} / \mathrm{L})$ & $1.14 \pm 0.20 \mathrm{~A}$ & $0.93 \pm 0.10 \mathrm{~A}$ \\
\hline Dissolved oxygen $(\mathrm{mg} / \mathrm{L})$ & $4.55 \pm 0.71 \mathrm{~A}$ & $4.00 \pm 0.47 \mathrm{~A}$ \\
\hline Temperature $\left({ }^{\circ} \mathrm{C}\right)$ & $26.51 \pm 0.13 \mathrm{~A}$ & $26.80 \pm 0.40 \mathrm{~A}$ \\
$\mathrm{pH}$ & $7.59 \pm 0.10 \mathrm{~A}$ & $7.50 \pm 0.20 \mathrm{~B}$ \\
\hline Electric conductivity $(\mu \mathrm{S})$ & $302.57 \pm 68.11 \mathrm{~A}$ & $235.02 \pm 50.00 \mathrm{~B}$ \\
\hline
\end{tabular}

Different letters in rows present significant difference $5 \%$ by the Tukey test.

TABLE 3 Mean values of zootechnical performance and survival in larviculture of Betta splendens using different feed types

\begin{tabular}{lccc}
$\begin{array}{l}\text { Feed/ } \\
\text { Performance }\end{array}$ & Artemia & $\begin{array}{l}\text { Alternating } \\
\text { feeding regime }\end{array}$ & $\begin{array}{l}\text { Panagrellus } \\
\text { redivivus }\end{array}$ \\
\hline $\begin{array}{l}\text { Weight } \\
\text { gain (mg) }\end{array}$ & $22.0 \pm 2.0 \mathrm{~A}$ & $19.0 \pm 2.0 \mathrm{~B}$ & $9.0 \pm 3.0 \mathrm{C}$ \\
\hline $\begin{array}{l}\text { Survival (\%) } \\
\text { Uniformity }\end{array}$ & $61.51 \pm 15.00 \mathrm{~A}$ & $60.37 \pm 24.00 \mathrm{~A}$ & $55.67 \pm 14.70 \mathrm{~A}$ \\
$\begin{array}{l}\text { U) } \\
\text { (\%) }\end{array}$ & & $57.33 \mathrm{~A} \pm 22.30 \mathrm{~A}$ & $52.65 \pm 18.25 \mathrm{~A}$ \\
\hline
\end{tabular}

Different letters in rows present significant difference $5 \%$ by the Tukey test.

A highest weight gain was observed in fish receiving Artemia feed, followed by fish from alternating feeding regime treatment. The use of nematodes as live feed produced the lowest weight gain of the three treatments (Table 3, Figure 1). The parameters of survival and uniformity do not present significant differences between the feed types used.

With regard to the SGR parameter, an effect of water depth and feed type or strategy used was observed (Table 5). The alternating feeding regime at a water depth of $2.5 \mathrm{~cm}$ produced a similar SGR to fish fed with Artemia only. At a 5-cm water depth, an improvement in SGR was observed in feed containing Artemia; however, the similarity still remained between Artemia feed and the alternating feeding regime.

The larvae fed only with nematodes had a lower SGR compared with another treatment, independent of water depth (Table 5).

\section{DISCUSSION}

The water quality parameters influence the survival and development of larvae. However, despite of variation in water quality, the parameters remained within the recommended range for betta fish culture according to Faria et al. (2006), independent of feed type or water depth used.

The higher value of total ammonia obtained with nematode feed may be explained by residue of oatmeal medium that was offered to larvae along with the nematodes; this was also reported by Martínez and Luengas (1998). This indicates that cleaning methods to remove the oatmeal medium should be developed to prevent the increase in total ammonia. In contrast, the lowest value of total ammonia was demonstrated with the Artemia treatment, possibly indicating

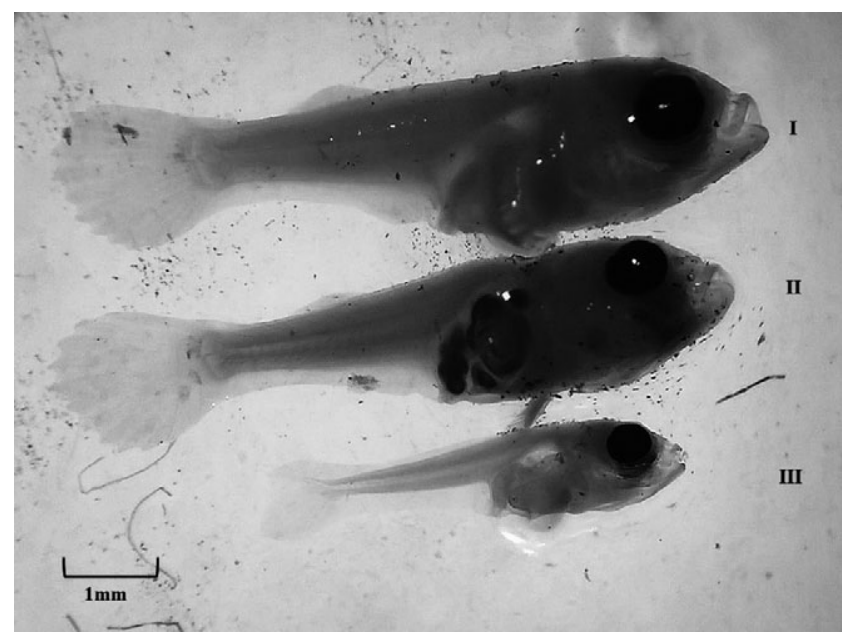

FIGURE 1 Development of larvae of Betta splendens at the end of the experiment: I. Larva fed exclusively with artemia; II. Larva fed with artemia and nematodes (Alternative feeding regime); III. Larva fed exclusively with nematodes

TABLE 4 Mean values of zootechnical performance and survival in larviculture of Betta splendens at different water depths

\begin{tabular}{lcc} 
Water column/Performance & $2.5 \mathrm{~cm}$ & $5.0 \mathrm{~cm}$ \\
\hline Weight gain (mg) & $15.0 \pm 6.0 \mathrm{~B}$ & $18.0 \pm 5.5 \mathrm{~A}$ \\
\hline Survival (\%) & $58.97 \pm 20.00 \mathrm{~A}$ & $59.40 \pm 15.00 \mathrm{~A}$ \\
\hline Uniformity (\%) & $54.25 \pm 17.30 \mathrm{~A}$ & $62.75 \pm 18.00 \mathrm{~A}$ \\
\hline
\end{tabular}

TABLE 5 Mean values of especific growth rate* in Betta splendens larviculture using different feed types and at different water depths

\begin{tabular}{llll}
$\begin{array}{l}\text { Feed/Water } \\
\text { column }\end{array}$ & Artemia & $\begin{array}{l}\text { Alternating } \\
\text { feeding regime }\end{array}$ & $\begin{array}{l}\text { Panagrellus } \\
\text { redivivus }\end{array}$ \\
\hline $2.5 \mathrm{~cm}$ & $12.80 \pm 0.76 \mathrm{Ba}$ & $12.48 \pm 0.75 \mathrm{Aa}$ & $6.91 \pm 1.64 \mathrm{Bb}$ \\
\hline $5.0 \mathrm{~cm}$ & $14.19 \pm 0.94 \mathrm{Aa}$ & $13.20 \pm 0.54 \mathrm{Aa}$ & $9.79 \pm 0.25 \mathrm{Ab}$
\end{tabular}

Different Lowercase letters in rows present significant difference $5 \%$ by Tukey test, and different uppercase letters in columns present significant difference $5 \%$ by Tukey test.

${ }^{*}$ Specific growth rate $(\%)=100$ (In final weight - In initial weight/time in days).

complete artêmia consumption which prevented the increase in total ammonia; an unexpected fact because of the excess of Artemia perishes in fresh water (Jomori, Luz, Takata, Fabregat, \& Portella, 2013). The Artemia treatment also increased $\mathrm{pH}$ at a water depth of $2.5 \mathrm{~cm}$, probably caused by remnants of salty water used for hatching Artemia nauplii, as reported by Kim (2007).

With regard to zootechnical performance, Artemia treatment produced the best results with the higher water depth, possibly due to higher feed availability throughout the column which increased the visual stimuli that are important to predation behaviour (Valentin et al., 2013). The improvement in larval growth with Artemia feed at a $5-\mathrm{cm}$ water depth was also verified by Kim (2007).

With regard to nematode treatment, the decanting factor cited by Sautter et al. (2007) was not the limiting factor for growth of betta larvae since, regardless of water depth used, the poorest 
productive performance was observed with $P$. redivivus only treatment. Similar result was observed to larvaculture of Hoplias malabaricus with the poorest productive performance to the $P$. redivivus treatment (Pereira, Mendonça, Pellanda, Matielo, \& Junior, 2015). This indicates that, despite the bromatological profile with high protein level, some other component not yet evaluated but theorized by Luna-Figueroa et al. (2010) (e.g., difficultly in digesting nematode cuticle) interferes with nutrient utilization.

The hypothesis of Luna-Figueroa et al. (2010) is plausible for though betta larvae complete morphological development of the digestive tract occurs 72 hours after hatching (Valentin et al., 2013), some digestive enzymes production yet increase during the betta larvae growth (Thongprajukaew, Kovitvadhi, Kovitvadhi, Engkagul, \& Rungruangsak-Torrissen, 2013), indicating that the larvae do not have specific capacity for efficient digestion of nematodes or an enzyme would not yet be fully available at this stage of larval development. This difference in larval digestive capacity in relation to different feeds was observed in flounder (Hippoglossus hippoglossus) which possess better ability to digest copepod than Artemia (Luizi, Gara, Shields, \& Bromage, 1999). Thus, in the case of betta larvae, the larvae were able to digest Artemia, but had difficulties in digesting nematodes, probably due to the lower amount or the lack of enzymes for digestion of nematode.

This feed digestion characteristic seems to be species specific as the nematode $P$. redivivus has already been successfully evaluated in larviculture of shrimps, being indicated as a partial replacement for Artemia (Martínez \& Luengas, 1998). Some species present lower amount specific digestive enzymes or do not present them, altering its digestion ability (Kolkovski, 2001).

Nonetheless, the inclusion of nematodes in the alternating feeding regime produced similar values for SGR to those of larvae fed Artemia only, with both water depths. This finding demonstrates that, despite the difficulties involved in nematode digestion, there was an influence of Artemia feed which had a positive effect on SGR, probably reflected by the assist from live feed enzymes in the digestion process (Kolkovski, 2001).

Therefore the alternated feed strategy to betta larviculture was feasible promoting reductions costs. Similar alternating feeding regime has already been validated as demonstrated for betta larvae that were fed with rotifers, Artemia and algae (Puello-Cruz et al., 2010) reducing costs in comparison with exclusive use of Artemia.

New feed strategies that enable better performance with reduced costs are important for the development of betta larvae production. For this reason, the use of alternating feeding regime containing Artemia and P. redivivus represents a lower cost alternative compared to feeding only with Artemia nauplii.

\section{5 | CONCLUSION}

The alternating feeding regime with Artemia and nematode is the most appropriate feeding system for $B$ splendens larviculture independent of the water depth used.

\section{ACKNOWLEDGMENTS}

The authors thank the National Council of Scientific and Technological Development (CNPq) for financial support to Rodrigo Yudi Fujimoto (305195/2016-6).

\section{ORCID}

Joel Artur Rodrigues Dias iD http://orcid.org/0000-0001-9751-0207 Peterson Emmanuel Guimarães Paixão iD http://orcid.org/00000002-8949-4232

Fernanda dos Santos Cunha (iD http://orcid.org/0000-0003-28837542

\section{REFERENCES}

Budiardi, T., Nursyams, T., \& Sudrajat, A. O. (2005). Survival rate and growth of fighting fish larvae (Betta splendens Regan) fed on various live foods. Jurnal Akuakultur Indonesia, 4, 13-16.

Das, P., Mandal, S. C., Bhagabati, S. K., Akhtar, M. S., \& Singh, S. K. (2012). Important live food organisms and their role in aquaculture. Frontiers in Aquaculture, 5, 69-86.

De Lara, R., Castro, T., Castro, J., \& Castro, G. (2007). Cultivo del nematodo Panagrellus redivivus (Goodey, 1945) en un medio de avena enriquecida con Spirulina sp. Revista de biología marina y oceanografía, 42, 29-36.

Fabregat, T. E. H. P., Wosniak, B., Takata, R., Miranda Filho, K. C., Fernandes, J. B. K., \& Portella, M. C. (2017). Larvicultura do betta em água levemente salinizada. Boletim do Instituto de Pesca, 43, 164-171. https://doi.org/10.20950/1678-2305.2017v43n2p164

Faria, P. M. C., Crepaldi, D. V., Teixeira, E. A., Ribeiro, L. P., Souza, A. B., Carvalho, D. C., \& Saliba, E. O. S. (2006). Criação, manejo e reprodução do peixe Betta splendens (Regan 1910). Revista Brasileira de Reprodução Animal, 30, 134-149.

Furuya, W. M., de Souza, S. R., Furuya, V. R. B., Hayashi, C., \& Ribeiro, R. P. (1998). Dietas peletizada e extrusada para machos revertidos de tilápias do Nilo (Oreochromis niloticus L.), na fase de terminação. Ciência Rural, 28, 482-487.

Jomori, R. K., Luz, R. K., Takata, R., Fabregat, T. E. H. P., \& Portella, M. C. (2013). Água levemente salinizada aumenta a eficiência da larvicultura de peixes neotropicais. Pesquisa Agropecuária Brasileira, 48, 809-815. https://doi.org/10.1590/S0100-204X2013000800001

Kim, C. Y. (2007). Efeito de Dietas e Altura da Coluna d'Água na Sobrevivência de Larvas de Betta splendens e o Aporte de Nitrogênio e Fósforo.

Kolkovski, S. (2001). Digestive enzymes in fish larvae and juveniles-implications and applications to formulated diets. Aquaculture, 200, 181-201. https://doi.org/10.1016/s0044-8486(01), 00700-1

Lazzari, R., Neto, J. R., Lima, R., Pedron, F., \& Losekann, M. (2004). Efeito da freqüência de arraçoamento e da troca do tamanho de partícula alimentar no desenvolvimento de pós-larvas de jundiá (Rhamdia quelen). Current Agricultural Science and Technology, 10, 231-234.

Luizi, F. S., Gara, B., Shields, R. J., \& Bromage, N. R. (1999). Further description of the development of the digestive organs in Atlantic halibut (Hippoglossus hippoglossus) larvae, with notes on differential absorption of copepod and Artemia prey. Aquaculture, 176, 101-116. https://doi.org/10.1016/S0044-8486(99)00054-X

Luna-Figueroa, J., Vargas, Z. T. de J., \& Figueroa, T. J. (2010). Alimento vivo como alternativa en la dieta de larvas y juveniles de Pterophyllum scalare (Lichtenstein, 1823). Avances en Investigación Agropecuaria, 14, 63-72. 
Martínez, G. E. P., \& Luengas, E. J. V. (1998). Sustitución de Artemia por nematodos en la alimentación de postlarvas (PL 6 a PL 10) del camarón marino (Penaeus vannamei boone 1936). Uniciencia, 15, 49-55.

Pereira, S. L., Mendonça, P. P., Pellanda, A. S., Matielo, M. D., \& Junior, L. P. G. (2015). Utilização de diferentes alimentos na larvicultura de traíra (Hoplias malabaricus). Brazilian Journal of Veterinary Medicine, 37, 233-238.

Puello-Cruz, A. C., Velasco-Blanco, G., Martínez-Rodríguez, I. E., FelixRamos, E., \& Voltolina, D. (2010). Growth and survival of siamese fighting fish, Betta Splendens, larvae at low salinity and with different diets. Journal of the World Aquaculture Society, 41, 823-828. https://d oi.org/10.1111/j.1749-7345.2010.00425.x

Ramos, F. M., Abe, H. A., \& Fujimoto, R. Y. (2016). Survival and growth of early life stages of leaf fish (Monocirrhus polyacanthus, Heckel 1840) cultured under different stocking densities and live food densities. Journal of Applied Ichthyology, 32, 954-959. https://doi.org/10.1111/jai. 13092

Sautter, J., Kaiser, H., Focken, U., \& Becker, K. (2007). Panagrellus redivivus (Linné) as a live food organism in the early rearing of the catfish Synodontis petricola (Matthes). Aquaculture research, 38, 653-659. https://doi.org/10.1111/j.1365-2109.2007.01714.x

Schlechtriem, C., Ricci, M., Focken, U., \& Becker, K. (2004). The suitability of the free living nematode Panagrellus redivivus as live food for first feeding fish larvae. Journal of Applied Ichthyology, 20, 161-168. https://doi.org/10.1111/j.1439-0426.2004.00542.x
Soares, C. M., Hayashi, C., Gonçalves, G. S., Galdioli, E. M., \& Boscolo, W. R. (2008). Plâncton, Artemia sp, dieta artificial e suas combinações no desenvolvimento e sobrevivência do quinguio (Carassius auratus) durante a larvicultura. Acta Scientiarum. Biological Sciences, 22, 383388.

Thongprajukaew, K., Kovitvadhi, U., Kovitvadhi, S., Engkagul, A., \& Rungruangsak-Torrissen, K. (2013). Evaluation of growth performance and nutritional quality of diets using digestive enzyme markers and in vitro digestibility in Siamese fighting fish (Betta splendens Regan, 1910). African Journal of Biotechnology, 12, 1689-1702. https://doi. org/10.5897/AJB12.2051

Valentin, F. N., do Nascimento, N. F., da Silva, R. C., Fernandes, J. B. K., Giannecchini, L. G., \& Nakaghi, L. S. O. (2013). Early development of Betta splendens under stereomicroscopy and scanning electron microscopy. Zygote, 23, 247-256. https://doi.org/10.1017/ s0967199413000488

How to cite this article: Couto MVSD, Sousa NDC, Abe HA, et al. Effects of live feed containing Panagrellus redivivus and water depth on growth of Betta splendens larvae. Aquac Res. 2018;00:1-5. https://doi.org/10.1111/are.13727 